\title{
Analysis of Stock Market Integration Among ASEAN Countries by Using Vector Error Correction Model (VECM) Approach
}

\author{
Reni Lestari \\ Institut Bisnis Nusantara \\ E-mail address_rereni12@gmail.com
}

\begin{abstract}
Globalization has driven the economy of countries to relate to each other. It brings relationships in the capital among countries in the world, especially in ASEAN region countries. This study aimed to analyze the integration of the stock market among countries in the ASEAN region. The stock market was analyzed are the Indonesia Stock Exchange, Malaysia Stock Exchange, Singapore Stock Exchange, Thailand Stock Exchange, Vietnam Stock Exchange, and Philippine Stock Exchange. This study using the Vector Error Correction Model (VECM) as the method. The result of this study shows that, in the long term Singapore Stock Index (STI), Malaysia Stock Index (KLSE), Philippines (PSEi), and Indonesia Stock Index (JKSE) are positively correlated. This means the change of stock index price in one country will affect other related countries in the long term. In the short term of VECM estimation, found the Vietnam Stock Index (VNI), Singapore Stock Exchange (STI), Philippine (PSEi) are positively correlated and negatively correlated with Thailand Stock Exchange (SET). For the managerial implication, the result of this study is expected as a reference or basis of consideration of investment decisions. This because long-term stock market movements are important because they impact international portfolio management and risk diversification.
\end{abstract}

Keywords: Integration, Capital Market, ASEAN, VAR/VECM

\section{INTRODUCTION}

This is an open access article under the CC-BY-NC license.

Globalization has changed everything in the world, especially in the economic sector. It changes the economic system of countries into an open economic system. The open system of a country's economy can make the country mutually integrated and mutually dependent on one another. Mutual integration between countries will make relations between countries are getting stronger and create obstacles in doing so, trade between countries will disappear, and capital mobility between countries will be smoother. However, in addition to providing many benefits, it will also have a negative impact. Namely, countries will quickly respond to the influence of countries experiencing a crisis. The stability of the country's economy is also determined by events that occurred both domestically and externally. Event volatility in other major countries to affect the condition of the nation's economy; in the end, it will have an impact on the stock price movement of capital market integration in a particular area. 
Usually, a strong country's economy can affect a weaker country's economy. As well in terms of investment. Today, investing activities are no longer limited by distance, time, and place. This is due to technological developments that make the capital market in the world able to integrate. With the integrated capital market in the world, investors can estimate the return that will be obtained in the capital market, where he invests capital with the integrated capital markets of other countries. In Asia, especially in ASEAN countries, the stock market in those countries are interesting for investors, due to the ASEAN countries mostly consist of developing countries and investment especially in the stock market in developing countries have a higher return than developed countries.

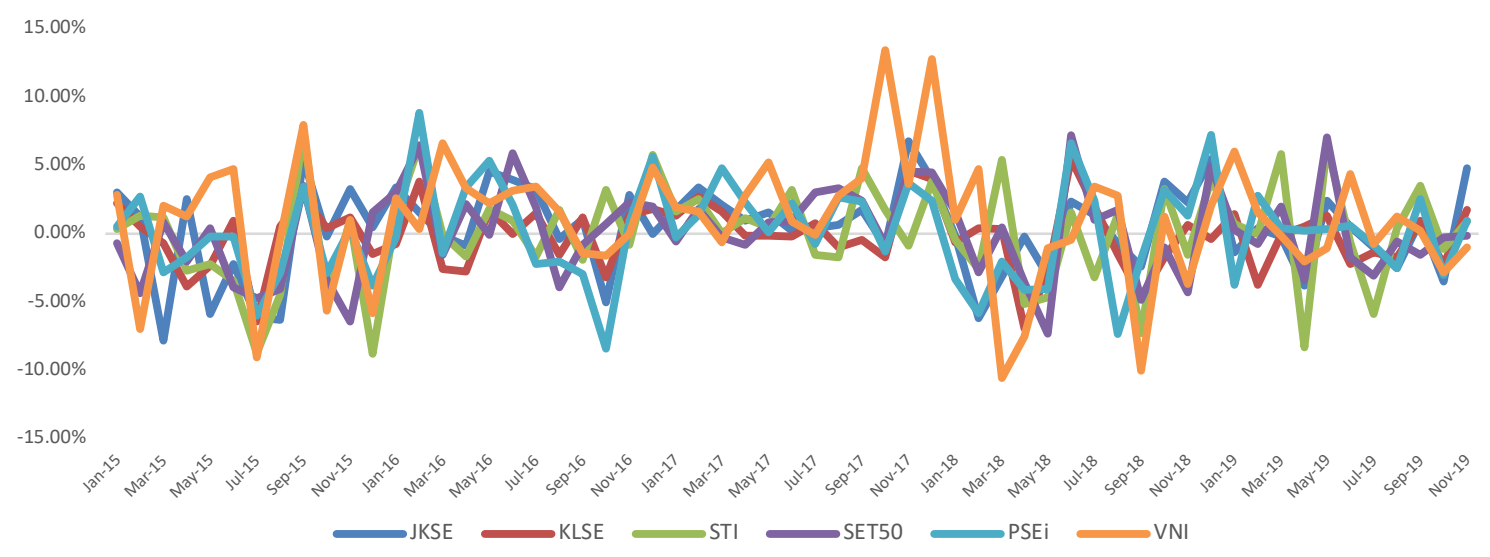

Figure 1. Stock Index Performance of ASEAN Countries

Integration in the capital market could lead to some advantages and disadvantages. The advantage of this integration makes the stock market more competitive; each county will attempt to facilitate investors in order to make investors interested to invest in their countries. Because it is important for countries due to capital market has big potential to gain funds. But on the investor's side, the integration of the capital market among counties could increase their systematic risk, risk, which can not be avoided through diversification.

\section{LITERATURE REVIEW}

Capital market is a market where bridging between those who needed long-term funds (company) and those (investors) who are needed investment instruments on financial products such as stocks, bonds, mutual funds, and others. On the other hand, stock markets are where government and industry can raise long-term capital, and investors can purchase and sell securities (Masoud, 2011). Not only government institutions but also private companies can raise log-term capital through the capital market. A stock market stock index is a statistical measurement, typically using weighted arithmetic mean, which reflecting all stocks or certain stock price movements. Movement in the stock index is driven by the movement of each stock in the index, but not all stocks in the index could affecting the stock index movement; only stock which has a large market cap could affect it. An equity index is a portfolio of stocks, chosen according to simple, predefined rules, and designed to capture a particular investment style (Broby, 2011). A composite stock index functioned to know the rate of market performance in terms of its price movements. It also reflects the level of return of stocks (Wauran \& Tumbuan, 2017).

The integration in the capital market generally measures the integration of the global capital market from the perspective of price. A first approach is a direct approach, which involves the law of one price and price equality; a second approach is an indirect approach, which measures the level of price movement or the dependency between the capital market in the short-term and long-term. (Dhanaraj et al., 2013). A contagion Effect is a contagious event of an economic movement from 
one country or region to another country or region. According to Eichengreen, Andrew, and Charles (1996), The contagion effect can be caused by the existence of economic interdependence relationships such as macroeconomic similarities and relationships trade between countries. The second cause is more emphasis on the behavior of the originating investors from the asymmetry of information, collective behavior, and loss of trust without seeing the macro performance of the country concerned. Some studies have been conducted regarding the integration and contagious effect in the capital market. A study conducted by Robiyanto Robiyanto (2017) by using the Orthogonal Generalized Autoregressive Conditional Heteroscedasticity (OGARCH) approach found that the stock market in Indonesia, Malaysia, Thailand, and Singapore are integrated, but the Philippines stock market is not integrated. Another study also conducted by Neame and Raj, and Dhal by using the Johansen cointegration approach with daily and weekly data found that the GCC and Indian stock markets are integrated with other stock markets in the world. This means investing in the Indian Stock Market, offering international investors to diversify their portfolio risk. (Neame, 2002; Karim and Karim, 2008; Onour, 2009; Raj and Dhal, 2009).

This study analyzing whether the stock market among ASEAN countries are integrated and has a contagion effect potency by using a Vector Error Correction Model (VECM) approach. Vector Error Correction Model (VECM) is the restricted form of VAR due to the existence of non-stationary and cointegrated forms of data, which indicates a long-term relationship between variables in the VAR system. Vector Error Correction Model (VECM) is a model for analyzing time series data in a Vector Autoregressive (VAR) model, which is the stationary of the data at the first difference and has cointegration. Following is the general form of VAR, a model which is non-stationary variables:

$$
Y_{t}=\mu+a_{1} Y_{t-1}+a_{2} Y_{t-2}+a_{3} Y_{t-3}+\cdots+a_{p} Y_{t-p}+\varepsilon_{t}
$$

Where $Y_{t}$ is a vector containing the variable at a time $-t, a_{1}, a_{2}, a_{3}, \ldots, a_{p}$ is a parameter VAR (p), and $Y_{t-p}$ is a vector containing the variable at time $t-p$. From Equation (1) can be formed the VECM equation as follows:

$$
\Delta Y_{t}=\mu+a \beta^{\prime} Y_{t-1}+\sum_{i=1}^{k} \Gamma_{i} \Delta Y_{t-1}+\varepsilon_{t}
$$

Where, $\Delta$ is a differencing operator, with $\Delta y_{t}=y_{t}-a t-1, \Gamma_{i}$ is a matrix coefficient ( $p \times p ; j=1,2,3, \ldots, k, \mu$ is a vector $(p \times 1)$ which includes all determinant components in the system of equation, $a, \beta$ stands for matrix $(p x r) ; 0<r<p$ and $r$ stand for the number of linear combinations of $X_{t}$ which only effected by shock transistor $\beta^{\prime} Y_{t-1}$ : error correction term, namely the number of ballast inverting average on the cointegration vector on the data to $t-1$, and $a$ is a matrix of error correction coefficients.

\section{RESEARCH METHODOLOGY}

\section{III.1. Data}

Data used in this research is quantitative data, which is in the form of numbers and derived from secondary sources. The period of data used is from January 2015 to December 2019, which are including the historical data (the price of the stock index) of JKSE (Indonesia Composite Index), KLSE (Malaysia Composite Index), PSEi (Philippines Composite Index), SET (Thailand Composite Index), STI (Singapore Composite Index), VNI (Vietnam Composite Index). The stock price index of each country is transformed into a logarithmic (ln) form. The secondary data was obtained from investing.com, yahoo finance, related journal, and other relating literature. 


\section{III.2. Sampling Method}

The population in this research is all countries in ASEAN, which are there are ten countries included. But in this research only include six counties, that are Indonesia (JKSE), Malaysia (KLSE), Philippines (PSEi), Thailand (SET), Singapore (STI), Vietnam (VNI). The sampling method in this research is purposive sampling, which is set some criteria, (1) The country must have a stock market, (2) The stock market has established for long ago and has long performance in implementing domestic stock trading international stock trading, (3) Has complete data available on stock index price. By these criteria, then there are some countries that are not included, that are Myanmar, Laos, Brunei Darussalam, and Cambodia because the stock market in these countries is underdeveloped and not have complete data.

\section{III.3 Methodology}

A quantitative approach is used in this study due to the objective facts used as of how the reality of society is formed. Moreover, there are free values that can be measured and applying a statistical method for gathering the theory (Neuman, 2014). This research focusing on analyze a situation or a problem in order to explain the relationships between variables. The purpose of using an explanatory research model is to derive data and explain the relationships between stock Indexes in ASEAN countries. This research involved individual data observing (collecting) historical data from all global indices purposed in this proposal and also Jakarta Composite Index (JCI) in order to find out the relation between them.

This study using Vector Autoregression (VAR) and Vector Error Correction Model (VECM) method. The data processing in some stages in order to get the VAR/VECM model, which includes unit root testing, determining the optimum lag, VAR stability testing, cointegration testing, VECM, Impulse Response Function (IRF), and Variance Decomposition. Data processed by using E-Views 10 and Microsoft Excel.

\section{FINDING AND DISCUSSION}

\section{IV.1 Unit Root Test}

The problem which often occurs in analyzing time series data is stationary. The stationary test is the most important step which analyzing the unit root existence among the data. This test is carried out So that the regression results do not produce false regressions (false regression). False regression is a regression that describes the relationship between two or more visible variables statistically significant when, in fact, it is not. Regression is spurious usually has a high R2 and a visible tstatistics significance, but the results cannot be interpreted properly in reality.

This study uses Augmented Dickey-Fuller (ADF) to test data stationarity. If data based on the ADF test is not stationary, the solution is to differentiate the process. Test the unit root of each variable in the research model based on the ADF test at a level. The test results can be seen below:

Table 1. Data Stationarity test result

\begin{tabular}{ccccccc}
\hline \multirow{2}{*}{ Variable } & \multicolumn{3}{c}{ Level } & \multicolumn{2}{c}{ First Different } \\
\cline { 2 - 7 } & $\begin{array}{c}\text { ADF Test } \\
\text { Statistic }\end{array}$ & $\begin{array}{c}\text { Critical } \\
\text { Value 5\% }\end{array}$ & Probability & $\begin{array}{c}\text { ADF Test } \\
\text { Statistic }\end{array}$ & $\begin{array}{c}\text { Critical } \\
\text { Value 5\% }\end{array}$ & Probability \\
\hline JKSE & -0.8631 & -2.9117 & 0.7931 & -7.0152 & -2.9126 & 0.0000 \\
\hline KLSE & -1.9639 & -2.9117 & 0.3017 & -6.6150 & -2.9135 & 0.0000 \\
\hline STI & -1.7033 & -2.9126 & 0.4243 & -9.5868 & -2.9126 & 0.0000 \\
\hline SET & -1.2859 & -2.9117 & 0.6306 & -7.5985 & -2.9126 & 0.0000 \\
\hline PSEi & -2.1940 & -2.9117 & 0.2106 & -6.9647 & -2.9126 & 0.0000 \\
\hline VNI & -1.0038 & -2.9117 & 0.7465 & -6.4993 & -2.9126 & 0.0000 \\
\hline \hline
\end{tabular}


Source: Data Processed

Data are containing unit root at level or not stationer in the level stage. The value of probability at a level greater than $\mathrm{a}=5 \%$ this means to accept the null hypothesis, that is, there is a unit root in the data or not stationer. While, from the first difference result, the probability value is less than $\mathrm{a}=$ $5 \%$. It indicates that the data already stationed at the first difference and reject the null hypothesis.

\section{IV.2 Optimum Lag Test}

The optimum lag test is very important in the VAR model. The lag used in the VAR can be determined based on criteria for AIC, SC, or HQ. The optimum lag length test is very useful for eliminating autocorrelation problems in VAR systems so that with the use of optimal lag, it is hoped that problems will no longer arise autocorrelation. (Nugroho, 2009)

Table 2. Optimum Lag test result

\begin{tabular}{ccccccc}
\hline Lag & $\operatorname{LogL}$ & LR & FPE & AIC & SC & HQ \\
\hline 0 & -2042.061 & NA & $8.90 \mathrm{e}+24$ & 74.47493 & 74.69391 & 74.55961 \\
\hline 1 & -1818.009 & 391.0728 & $9.62 \mathrm{e}+21^{*}$ & $67.63667^{*}$ & $69.16955^{*}$ & $68.22945^{*}$ \\
\hline 2 & -1797.232 & 31.73147 & $1.75 \mathrm{e}+22$ & 68.19025 & 71.03702 & 69.29112 \\
\hline 3 & -1749.673 & $62.25924^{*}$ & $1.30 \mathrm{e}+22$ & 67.76992 & 71.93057 & 69.37888 \\
\hline 4 & -1712.557 & 40.49014 & $1.61 \mathrm{e}+22$ & 67.72934 & 73.20388 & 69.84639 \\
\hline 5 & -1684.577 & 24.41904 & $3.42 \mathrm{e}+22$ & 68.02097 & 74.80941 & 70.64611 \\
\hline
\end{tabular}

Source: Data Processed

\section{IV.3 VAR Stability Test}

The stability of VAR needs to be tested first before carrying out a further analysis because if the VAR estimation results are combined with the correction model, unstable error, hence IRF (Impulse Response Function) and Variance Decomposition will be invalid (Setiawan, 2007 in Rusydiana, 2009). Following is the result of the VAR Stability test:

Table 3. VAR Stability test result

\begin{tabular}{lc}
\hline Root & Modulus \\
\hline$-0.092997-0.680712 \mathrm{i}$ & 0.687035 \\
\hline$-0.092997+0.680712 \mathrm{i}$ & 0.687035 \\
\hline $0.425498-0.429899 \mathrm{i}$ & 0.604865 \\
\hline $0.425498+0.429899 \mathrm{i}$ & 0.604865 \\
\hline 0.574614 & 0.574614 \\
\hline$-0.554484-0.093160 \mathrm{i}$ & 0.562256 \\
\hline$-0.554484+0.093160 \mathrm{i}$ & 0.562256 \\
\hline$-0.513550-0.140668 \mathrm{i}$ & 0.532467 \\
\hline$-0.513550+0.140668 \mathrm{i}$ & 0.532467 \\
\hline $0.024742-0.352552 \mathrm{i}$ & 0.353419 \\
\hline $0.024742+0.352552 \mathrm{i}$ & 0.353419 \\
\hline 0.029317 & 0.029317 \\
\hline \multicolumn{2}{c}{ Source: Data Processed }
\end{tabular}

It can be seen that there is no root containing the value of one or greater in each modulus value, which means the VAR model is stable.

\section{IV.4 Cointegration Test}

The purpose of the cointegration test is to find out whether there will be a balance in the long term. That is, there are limits to the movement and stability of the relationship between the variables 
in this study or not. In this research cointegration test was conducted by using Johansen's Cointegration Test. Below is the result of the cointegration test :

Table 4. Cointegration test result (Trance Statistic)

\begin{tabular}{ccccc}
\hline $\begin{array}{c}\text { Hypothesized } \\
\text { No. of CE(s) }\end{array}$ & Eigenvalue & $\begin{array}{c}\text { Trace } \\
\text { Statistic }\end{array}$ & $\begin{array}{c}0.05 \\
\text { Critical Value }\end{array}$ & Prob.** $^{* *}$ \\
\hline None $^{*}$ & 0.599763 & 128.8427 & 95.75366 & 0.0000 \\
\hline At most 1 & 0.504997 & 76.64795 & 69.81889 & 0.0129 \\
\hline At most 2 & 0.307448 & 36.56609 & 47.85613 & 0.3683 \\
\hline At most 3 & 0.164157 & 15.62586 & 29.79707 & 0.7383 \\
\hline At most 4 & 0.065491 & 5.404936 & 15.49471 & 0.7644 \\
\hline At most 5 & 0.026725 & 1.544071 & 3.841466 & 0.2140 \\
\hline
\end{tabular}

Source : Data Processed

Table 5. Cointegration test result (Max-Eigen Statistic)

\begin{tabular}{ccccc}
\hline $\begin{array}{c}\text { Hypothesized } \\
\text { No. of CE(s) }\end{array}$ & Eigenvalue & $\begin{array}{c}\text { Max-Eigen } \\
\text { Statistic }\end{array}$ & $\begin{array}{c}0.05 \\
\text { Critical Value }\end{array}$ & Prob.** \\
\hline None $^{*}$ & 0.599763 & 52.19475 & 40.07757 & 0.0014 \\
\hline At most 1 & 0.504997 & 40.08186 & 33.87687 & 0.0080 \\
\hline At most 2 & 0.307448 & 20.94023 & 27.58434 & 0.2799 \\
\hline At most 3 & 0.164157 & 10.22092 & 21.13162 & 0.7236 \\
\hline At most 4 & 0.065491 & 3.860866 & 14.26460 & 0.8737 \\
\hline At most 5 & 0.026725 & 1.544071 & 3.841466 & 0.2140 \\
\hline
\end{tabular}

Source: Data Processed

Can be seen, the results of trance statistic and maximum eigenvalue statistic show that there is one cointegrating equation among the variables in the ASEAN Stock index at $5 \%$ level of critical value, which means the set of cointegrated time series have an error-correction representation which is reflecting there is adjustment mechanism in the long-run.

\section{IV.5 Granger Causality Test}

Granger causality test was conducted in this study with the purpose of finding out the causality relationship between variables. Below is the result of the Granger causality test:

Table 6. Cointegration test result (Max-Eigen Statistic)

\begin{tabular}{lccr}
\hline Null Hypothesis: & Obs & F-Statistic & Prob. \\
\hline KLSE does not Granger Cause JKSE & 58 & 2.61616 & 0.0825 \\
JKSE does not Granger Cause KLSE & & 0.32087 & 0.7269 \\
\hline PSEI does not Granger Cause JKSE & 58 & 1.71526 & 0.1898 \\
JKSE does not Granger Cause PSEI & & 1.42095 & 0.2505 \\
\hline SET does not Granger Cause JKSE & 58 & 1.10371 & 0.3391 \\
JKSE does not Granger Cause SET & & 6.77962 & 0.0024 \\
\hline STI does not Granger Cause JKSE & 58 & 2.42913 & 0.0979 \\
JKSE does not Granger Cause STI & & 3.78592 & 0.029 \\
\hline VNI does not Granger Cause JKSE & 58 & 0.53263 & 0.5902 \\
JKSE does not Granger Cause VNI & & 5.92992 & 0.0047 \\
\hline PSEI does not Granger Cause KLSE & 58 & 0.34591 & 0.7092 \\
KLSE does not Granger Cause PSEI & & 0.52601 & 0.594 \\
\hline SET does not Granger Cause KLSE & 58 & 0.01869 & 0.9815 \\
KLSE does not Granger Cause SET & & 1.95483 & 0.1517 \\
\hline STI does not Granger Cause KLSE & 58 & 0.36281 & 0.6974 \\
\hline
\end{tabular}




\begin{tabular}{lccr}
\hline KLSE does not Granger Cause STI & & 1.83068 & 0.1703 \\
\hline VNI does not Granger Cause KLSE & 58 & 1.79645 & 0.1758 \\
KLSE does not Granger Cause VNI & 58 & 0.42786 & 0.6541 \\
\hline SET does not Granger Cause PSEI & & 0.23105 & 0.7945 \\
PSEI does not Granger Cause SET & 58 & 2.13689 & 0.1281 \\
\hline STI does not Granger Cause PSEI & & 0.11795 & 0.889 \\
PSEI does not Granger Cause STI & 58 & 2.89940 & 0.0638 \\
\hline VNI does not Granger Cause PSEI & & 1.04423 & 0.3591 \\
PSEI does not Granger Cause VNI & 58 & 7.29873 & 0.0016 \\
\hline STI does not Granger Cause SET & & 0.58917 & 0.5584 \\
SET does not Granger Cause STI & 58 & 1.84111 & 0.1686 \\
\hline VNI does not Granger Cause SET & & 4.95237 & 0.0107 \\
SET does not Granger Cause VNI & 58 & 3.79401 & 0.0288 \\
\hline VNI does not Granger Cause STI & & 1.68674 & 0.1949 \\
STI does not Granger Cause VNI & & 0.02251 & 0.9778 \\
\hline Source: Data Processed
\end{tabular}

Source: Data Processed

A probability value less than $a=5 \%$ indicates that there is a causality relationship. If one variable has a probability value less than a $=5 \%$, then there is a one-way causality relationship, and if both two variables have a probability value less than $\mathrm{a}=5 \%$, it indicates there is a two-way causality relationship.

\section{IV.6 The Vector Error Correction Model (VECM) Estimation Result}

After conducting several stages of testing, the model hints at VAR with test results shows there is one or more cointegration in the sets of variables, then the Vector Error Correction Model is suitable to apply. VECM estimation the resultant can only show a significant effect on lag, certainly both long term and short term in a way Comparing the estimated value t-hitung with the t-table value and based on t-test results, partially using a significant level of five percent with $t$ table value of 2.000298 .

This study found that, in the long term Singapore Stock Index (STI), Malaysia Stock Index (KLSE), Philippines (PSEi), and Indonesia Stock Index (JKSE) are positively correlated. This means the change of stock index price in one country will affect other related countries in the long term. This finding shows that the higher the index price will also increase the Indonesia Stock index price. The correlation between these countries occurs because there are linked to the economy in a related country.

In the short term of VECM estimation, found the Vietnam Stock Index (VNI), Singapore Stock Exchange (STI), Philippine (PSEi) are positively correlated and negatively correlated with Thailand Stock Exchange (SET). Shor-term effects are captured by the individual coefficients of the differentiated terms, which are capturing impact while the coefficient of the VECM variable containing information that the past values of variables could affect the current values of the observed variables. Also, the size and statistical significance of the coefficient of the error correction term measures the tendency of each variable to return to the equilibrium. Coefficient, which is significant, implies the past equilibrium errors play a role in determining the current outcomes that capture the long-run impact. 


\section{IV.7 Impulse Response Function}

IRF analysis will explain the impact of the shock on one variable on other variables, which in this analysis not only in a short time but can be analyzed for some future horizons as long-term information. Below is the result of the Impulse Response Function (IRF):

Response of STI to Innovations

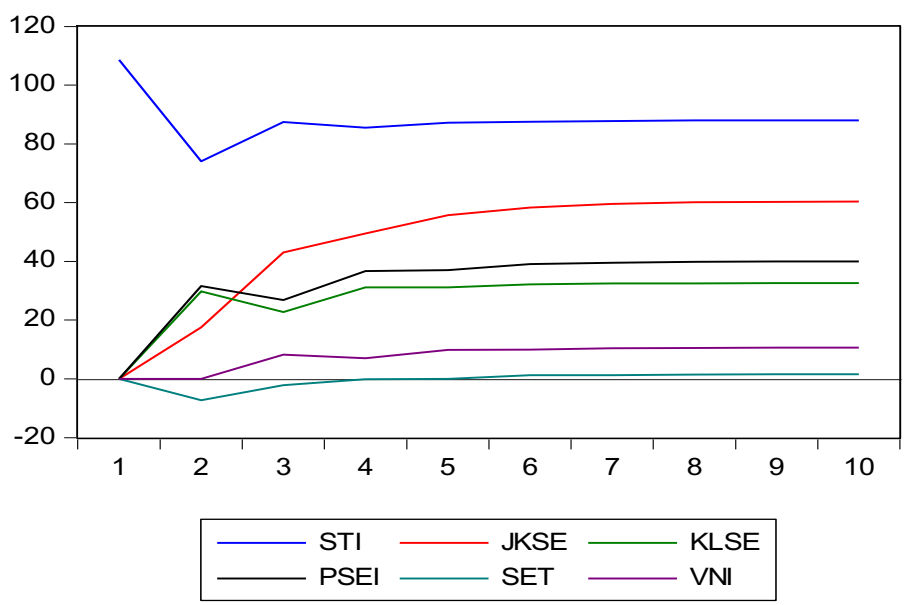

Figure 2. Impulse Response Function Result

The figure above explains the long-term dynamic response of JKSE, KLSE, PSEI, SET, and VNI, if there is a certain shock in STI equal to one standard error in each equation. Analysis of the impulse response function as well serves to see how long the effect lasts.

\section{IV.8 Forecast Error Variance Decomposition}

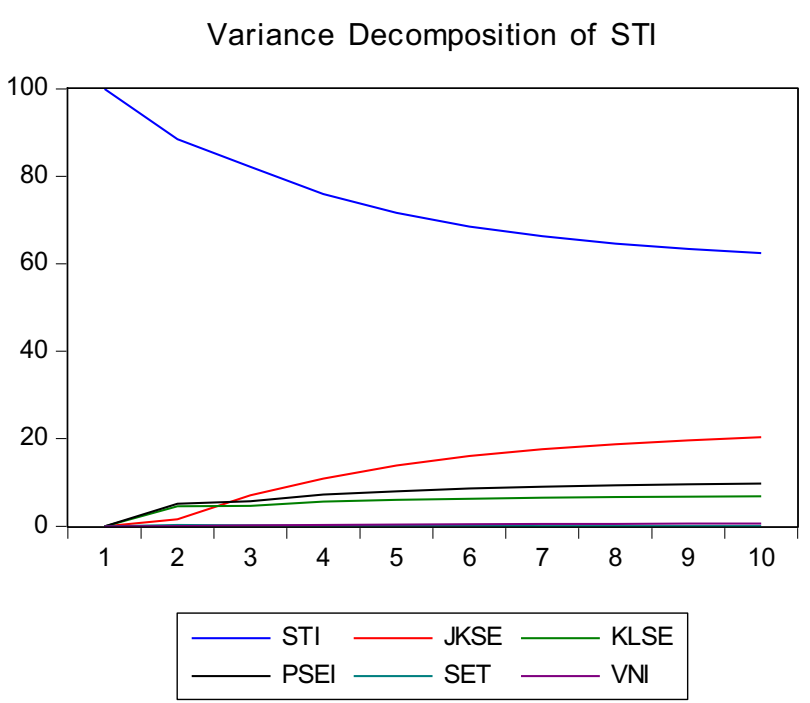

Figure 3. Variance Decomposition

Variance decomposition aims to measure the amount of contribution or composition of the influence of each independent variable on the variable dependents. Shows that the contribution to the diversity of the STI variable comes from the STI itself by $100 \%$ in the first period then decreased until the end of the period. 


\section{CONCLUSION AND FURTHER RESEARCH}

Based on the result of this study, it can be concluded that the study found that, in the long term Singapore Stock Index (STI), Malaysia Stock Index (KLSE), Philippines (PSEi), and Indonesia Stock Index (JKSE) are positively correlated. This means the change of stock index price in one country will affect other related countries in the long term. This finding shows that the higher the index price will also increase the Indonesia Stock index price. The correlation between these countries occurs because there are linked to the economy in a related country. In the short term of VECM estimation, found the Vietnam Stock Index (VNI), Singapore Stock Exchange (STI), Philippine (PSEi) are positively correlated and negatively correlated with Thailand Stock Exchange (SET). Shor-term effects are captured by the individual coefficients of the differentiated terms, which are capturing impact while the coefficient of the VECM variable containing information that the past values of variables could affect the current values of the observed variables.

The managerial implication of this study is expected to be a reference or basis of consideration of investment decisions. This because long-term stock market movements are important because they impact international portfolio management and risk diversification. For further research may add variables other than ASEAN countries in order to find out the opportunity of international investment and diversifying risk.

\section{REFERENCES}

Robiyanto (2017). The Analysis of Capital Market Integration in the ASEAN Region Using the OGARCH Approach. Finance and Banking Journal, 21(2), 169-175.

Suryanta, B (2011). Capital Market Integration in ASEAN Countries: Special Investigation of Indonesian Toward the Big Four. The Asian of Technology Management Vol.4 No. 2, (2011), $109-114$.

Fabozzi, F. (2007). Financial Econometrics: From Basics to Advanced Modelling Techniques. New York:

Wiley Finance.

Masoud (2011). The Impact of Stock Market Performance on Economic Growth. International Journal of Economics and Financial Issues Vol. 3, No. 4, (2013), 788-798.

Eichengreen, B., \& Rose, K. (1996). Contagious Currency Crises. NBER Working Paper Series 5681

Gujarati, D., (2004), Basic Econometrics, 4th Edition, New York: Mc. Graw Hill.

Andrei. L., \& Andrei, D. (2015). Vector error correction model in explaining the association of some macroeconomic variables in Romania. Procedia Economics and Finance 22, (2015), 568 - 576

Ni'mah, E., \& Yulianto, S., (2017). Peramalan Laju Inflasi dan Nilai Tukar Rupiah terhadap Dolar Amerika

dengan Menggunakan Model vector autoregressive (VAR) dan Vector Error Correction Model (VECM) [Forecasting the Rate of Inflation and the Exchange Rate of the Rupiah against the US Dollar Using the vector autoregressive model (VAR) and the Vector Error Correction Model (VECM). The 6th University Research Colloquium Universitas Muhammadiyah Magelang (2017)

www.investing.com

www.yahoofinance.com 